\title{
The value of legumes to a Whanganui hill country farm
}

J.M. RENDEL ${ }^{1}$, A.D. MACKAY ${ }^{2}$ and P.N. SMALE ${ }^{1}$

${ }^{1}$ AgResearch, Private Bag 50034, Mosgiel, New Zealand

${ }^{2}$ AgResearch, Private Bag 11008, Palmerston North 4422, New Zealand john.rendel@agresearch.co.nz

\section{Abstract}

There is interest in the sheep and beef sector in lifting the legume content of hill pastures. This interest is tempered by the uncertainty of the benefits and how much farmers can afford to spend to achieve them. The objective of this study was to quantify the value to a hill country farm of differing proportions of legumes in a mixed species pasture using AgInform ${ }^{\circledR}$ (Integrated Farm Optimisation and Resource Allocation Model). AgInform $^{\circledR}$ is a multi-year farm systems model, adapted so that the legume proportion of pasture as it influences pasture growth and animal performance through its influence on diet could be included as variables in the model. Three levels of legume (Low, Base and High) in a mixed pasture were modelled. The model predicts that increasing the legume proportion increases farm profitability although not in a linear manner with increasing legume proportion. This analysis provides an indication of the investment that hill country farmers can afford to increase the legume proportion in mixed pastures.

Keywords: farm systems, legume, variability, AgInform $^{\circledR}$, multi-year

\section{Introduction}

There is interest among the sheep and beef sector in lifting the legume proportion of sheep and beef hill pastures (Nelson et al. 2017). This is in an attempt to lift pasture quality for improving livestock performance and biological nitrogen $(\mathrm{N})$ fixation to increase pasture growth. Little nitrogenous fertiliser is used on New Zealand hill pastures and therefore they are heavily dependent on legumes for the $\mathrm{N}$ required to sustain production (Ball et al. 1979). The value of legumes in the diet of ruminants comes from two sources: that of a higher energy content of legumes (12 MJ ME $/ \mathrm{kg}$ DM; Holmes et al. (2002)) compared to other pasture species in the diet and from increased efficiency of ME for growth (see equation 38, Freer et al. (2012)). This influences the dry matter intake (DMI) of animals. With $\mathrm{N}$ still the macro-nutrient most limiting pasture growth on sheep and beef farms, lifting the growth and vigour of the legume proportion of pasture is a cost-effective way of lifting the quality and quantity of feed available to the animal (Lambert et al. 2003). The incentive to increase the proportion of animals finished to slaughter weights in hill county and the greater focus on per head erformance, requires lifting the legume proportion of existing hill pastures. Uncertainty exists around what the economic return might be and so how much farmers can afford to spend to lift on-farm performance.

AgInform $^{\circledR}$ (Integrated Farm Optimisation and Resource Allocation Model), is a multi-year farm systems model that advances the use of Linear Programming in whole-farm-systems modelling and decision making by integrating independently obtaine biological data for specific land management units

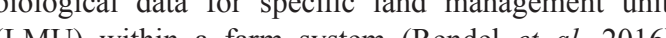
(Lisis) with a far systen (Rendel et al. 2016). This mode has the capacity to predict the expected eturns for the whole farm business from investment targeted at specific LMUs. As part of this development, AgInform ${ }^{\circledR}$ has been modified so that the legume percentage in the pasture as it influences the energy and dry matter requirements of the animal can vary with the season of the year and from year to year. Before the current version was assumed to be $20 \%$ of the diet for the purpose of calculating the $\mathrm{ME}$ and $\mathrm{DM}$ requirements of animals. The user provides input data about the resources available (land area, pasture and livestock performance including crops and nitrogen responses), costs (per hectare, per animal and enterprise) and prices (meat schedules); AgInform ${ }^{\circledR}$ identifies the entry stock policy at the beginning of the planning horizon and the exit strategy at the end. Capital stock can be purchased or

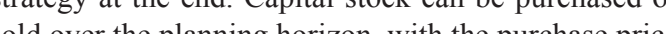
sold over the plang cring of of valuation, in an effort to represent scarcity of stock when purchased and over supply at sale time. The $\mathrm{Ne}$ Present Value (NPV) is maximised over the planning horizon. The objective of this study was to model, using AgInform ${ }^{\circledR}$, the value to a hill country farm of differing proportions of legumes in a mixed species pasture.

\section{Methods}

The pasture energy details provided to the model assumed that legumes contained $12 \mathrm{MJ}$ ME $/ \mathrm{kg}$ DM (Holmes et al. 2002). Further, the amount of $\mathrm{N}$ fixed by legumes impacts directly on the amount of forage grown. Nitrogen fixed is assumed to be $6.1 \%$ of the legume grown ( $\mathrm{kg} \mathrm{N}$ fixed $/ \mathrm{kg} \mathrm{DM} /$ ha legume produced) (Ledgard et al. 2001) 


\section{Farm description}

The Whanganui hill country sheep and beef farm has been used for a number of case studies (Rendel et al. 2013, 2015, 2016). The farm consists of 508 ha split into 4 LMUs (210, 179, 90 and $31 \mathrm{ha})$ producing on average $12.5,7.9,5.2$ and $10.2 \mathrm{tDM} / \mathrm{ha} / \mathrm{year}$, respectively. The costs associated with running the property were split into animal (ewes, cattle, replacements and finishing stock and include labour, animal health, etc.), land (consisting of fertiliser, R\&M, rates, etc.) andenteprise (costs (that do not fit Ririty whe included legal, accountancy, and communication). If farm accounts are available, these costs can be obtained from the Farm Working Expenses. The animal costs were converted to a per head basis using stock numbers from the stock reconciliation statement in the accounts. The land costs were converted to a hectare basis. If the farm accounts are not available then monitoring report for the farm location and type (e.g. MPI or Beef + Lamb New Zealand) can be used. The costs and prices remained constant over the planning horizon. The farm details have been described in Rendel et al. (2016).

\section{Farm systems modelling}

For the Whanganui farm the legume proportion of the pasture and the diet of the grazing animals was based on data collected in Gisborne at $314 \mathrm{~m}$ a.s.l. (Gray et al. 1987). On average, the legume proportion was $13 \%$ of the DM grown, with a minimum of $3 \%$ in mid-July through to a peak of $23 \%$ in late December and early January. This was selected as the base ('Base'). The low ('Low') legume proportion option used an annual average legume proportion of $2 \%$ on all the LMUs throughout the year, whilst still maintaining the seasonal variation. Pasture growth rates and $\mathrm{ME}$ were decreased to account for the low legume proportion. The high ('High') legume proportion was evalunted by doubling the legume proportion of the wase swatd by doch of the 4 LMU's whils mintaing intion. Fortnightly pasture growth rates and ME were both adjet to refect the exta leger. The farm was modled for each of the thee legne The farm was modelled for each of the three legume proportions (Base, Low and High) and the systems compared for both physical and economic performance. The cost of increasing the legume proportion was not included, as the break-even investment was bein estimated. The next step compared the value of additional leoume on different areas of the farm. The higher pature rowth LMUS (1 \& 4) af thewer gowh LMUs (2 \& 3$)$ were allocated different legume levels (Table 1) so that the contribution of additional legume on different areas of the farm could be valued.

Due to the model having complete knowledge over the 10 years and to better represent actual decision making on farm, capital stock (ewes and beef cows) numbers were required to be the same at 1 July each year and 17 June in the final year (as this is the last complete fortnightly period in the planning horizon). The model retained the option to purchase or sell capital stock between those dates, if it positively contributed to the NPV.

Pasture covers for each LMU were required to be on average between 1500 and $2500 \mathrm{~kg} \mathrm{DM} / \mathrm{h}$. Further, opening pasture covers for 1 July 1996 were set at 1500 $\mathrm{kg} \mathrm{DM} / \mathrm{ha}$ to best represent the covers at that time of year. If the model was allowed to choose the starting pasture cover it will invariably pick the upper level, $2500 \mathrm{~kg} \mathrm{DM} / \mathrm{ha}$ in this case. This does not represent the farm situation at that time of year.

The first model runs were set up to quantify the effect of increasing legume proportion over the whole farm. The second set of runs were to quantify the impact and value to the whole farm of changing legume proportion on just parts of the farm. To do this the highest pasture producing LMUs were grouped together (LMU $1 \& 4$ ) as were the two lower producing LMUs (2 \& 4). It was a a wered the the legume propolion of the porer producing the legume proportion of the poorer producing group would never be greater than the better group. Table
provides a description of the alternatives modelled.

\section{Farm systems analysis}

AgInform $^{\circledR}$ identified optimal farm systems that maximised the NPV of the annual Earnings Before Interest, Tax, Depreciation and Amortisation (EBITDAs), including the initial capital spent on (EBITAs), i livestock and their liquidated at the end of the 10 year planning horizon. EBITDA was used as a measure of annual profit as it does not include items associated with farm structure (tax rates, depreciation) nor debt (interest and amortisation). The annual EBITDA were discounted as if they occurred at the end of the year. The NPVs were converted to an annuity (equal payments per year that would be received from interest and capital such that no capital remained at the end of the planing horizo the planing horizon) using the same discount rate as used for the NPV (5\%/yea in this case). The discount rate should reflect the future ins-free rate, as inflation was not included in this analysis. The annuity makes it easier to visualise the returns from different investment

Table 1 Combinations of legume proportions on LMUs analysed within each farm system.

\begin{tabular}{lcc}
\hline Scenarios & LMU 1\&4 & LMU 2\&3 \\
\hline Low-Low & Low & Low \\
Base-Base & Base & Base \\
High-High & Double & Double \\
Base-Low & Base & Low \\
High-Low & Double & Low \\
High-Base & Double & Base \\
\hline
\end{tabular}

options. This type of investment analysis was required due to differing numbers of animals at the beginning and end of the planning horizon. The NPVs (and annuities) can be compared to the base system (usually current system optimised) to identify and quantify the best investment. The next step after the investment analysis, would be a funding analysis - how could the farm fund this investment? This would include the existing debt levels, capital structure and tax. It is possible that

\begin{tabular}{|c|c|c|c|c|c|c|c|}
\hline & \multirow[t]{2}{*}{ Stock Value (\$) } & \multirow[t]{2}{*}{ Ewes $^{1}$} & \multicolumn{2}{|c|}{ Lambs Sold } & \multicolumn{2}{|c|}{ Cattle Sold } & \multirow[t]{2}{*}{ EBITDA (\$) } \\
\hline & & & Head & Date $^{2}$ & Head & Date $^{2}$ & \\
\hline 1996 & -748885 & & & & & & \\
\hline 1996/1997 & & 4153 & 4692 & 13 April & 31 & 29 Jan. & 315806 \\
\hline 1997/1998 & & 4153 & 4671 & 16 May & & & \\
\hline \multicolumn{8}{|l|}{433109} \\
\hline 1998/1999 & & 4153 & 4686 & 22 April & & & 381041 \\
\hline 1999/2000 & & 4153 & 4688 & 19 April & & & 377816 \\
\hline 2000/2001 & & 4153 & 4688 & 18 April & & & 331811 \\
\hline $2001 / 2002$ & & 4153 & 4673 & 13 May & 130 & 18 April & 437499 \\
\hline 2002/2003 & & 4153 & 4731 & 11 Feb. & & & 223534 \\
\hline 2003/2004 & & 4153 & 4670 & 17 May & & & 442718 \\
\hline 2004/2005 & & 4153 & 4689 & 20 April & 75 & $18 \mathrm{Jan}$. & 360742 \\
\hline 2005/2006 & & 4153 & 5715 & 19 April & 169 & 27 May & 551219 \\
\hline 2006 & 625631 & & & & & & \\
\hline NPV & & & & & & & 2584700 \\
\hline Annuity & & & & & & & 334730 \\
\hline
\end{tabular}

${ }^{1}$ Ewes present at start of lambing ${ }^{2}$ Average sale date

Table 3 Summary of farm system and financial analysis with Base (average of 13\% of DM across the year) legume proportion.

\begin{tabular}{|c|c|c|c|c|c|c|c|}
\hline \multirow[t]{2}{*}{ 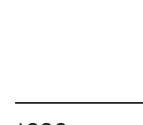 } & \multirow[t]{2}{*}{ Stock Value (\$) } & \multirow[t]{2}{*}{ Ewes $^{1}$} & \multicolumn{2}{|c|}{ Lambs Sold } & \multicolumn{2}{|c|}{ Cattle Sold } & \multirow[t]{2}{*}{ EBITDA (\$ } \\
\hline & & & Head & Date $^{2}$ & Head & Date $^{2}$ & \\
\hline 1996 & -907257 & & & & & & \\
\hline 1996/1997 & & 4718 & 5254 & 11 April & 102 & 29 Jan. & 349277 \\
\hline 1997/1998 & & 5031 & 5662 & 11 May & 27 & 4 June & 532560 \\
\hline 1998/1999 & & 5031 & 5679 & 19 April & & & 479647 \\
\hline 1999/2000 & & 5031 & 5685 & 11 April & & & 466585 \\
\hline $2000 / 2001$ & & 5031 & 5684 & 13 April & & & 422407 \\
\hline 2001/2002 & & 5393 & 6166 & 3 May & 66 & 4 June & 532379 \\
\hline 2002/2003 & & 5031 & 5730 & 13 Feb. & & & 300690 \\
\hline 2003/2004 & & 5031 & 5662 & 11 May & 20 & 4 June & 524142 \\
\hline 2004/2005 & & 5031 & 5685 & 14 April & 134 & $28 \mathrm{Jan}$. & 447465 \\
\hline 2005/2006 & & 5031 & 6929 & 14 April & 215 & 4 June & 679933 \\
\hline 2006 & 757937 & & & & & & \\
\hline NPV & & & & & & & 3174490 \\
\hline Annuity & & & & & & & 411111 \\
\hline
\end{tabular}

investment has a favourable NPV yet the farm is not ble to fund that investment and that option is not taken Results

Comparison of different proportions of legume Cross the whole farm

The optimal farm systems for Low, Base and Hig legume proportions (Tables 2, 3 and 4, respectively)

${ }^{1}$ Ewes present at start of lambing ${ }^{2}$ Average sale dale 
varied in several ways including the amount of capital indicates that the constraint requiring ewe numbers to invested and liquidated in livestock, the number of be equal each year as at 1 July could be relaxed for the ewes present lit a in the number of lambs sold, the timing of lamb sales, feed and fed it out in July 1996. Furthermore, they the number of cattle purchased to finish and their sale also applied nitrogen at the beginning of July 1996 dates. Annual EBITDA, NPV and annuity also varied. to maintain pasture covers above the LMU minimum All farm systems exhibited variation in EBITDA across $\quad(1500 \mathrm{~kg}$ DM/ha). All farm systems also sold all ewe years and most systems kept ewe numbers at lambing lambs as prime in the final year, rather than keeping

constant. In the Base and High systems ewes were sold some as replacements and being valued as capital stock as culls at scanning in the 1996/1997 year This perhaps at the end of the planning horizon

Table 4 Summary of farm system and financial analysis with High (average of 27\% of DM across the year) legume proportion.

\begin{tabular}{|c|c|c|c|c|c|c|c|}
\hline \multirow[t]{2}{*}{ 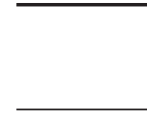 } & \multirow[t]{2}{*}{ Stock Value (\$) } & \multirow[t]{2}{*}{ Ewes $^{1}$} & \multicolumn{2}{|c|}{ Lambs Sold } & \multicolumn{2}{|c|}{ Cattle Sold } & \multirow[t]{2}{*}{ EBITDA (\$) } \\
\hline & & & Head & Date $^{2}$ & Head & Date $^{2}$ & \\
\hline 1996 & -1134290 & & & & & & \\
\hline 1996/1997 & & 5436 & 5936 & 5 April & 196 & 2 Feb. & 325487 \\
\hline 1997/1998 & & 6290 & 7094 & 25 April & 63 & 12 Feb. & 632350 \\
\hline 1998/1999 & & 6290 & 7108 & 11 April & & & 606924 \\
\hline $1999 / 2000$ & & 6290 & 7118 & 1 April & & & 580506 \\
\hline 2000/2001 & & 6290 & 7113 & 6 April & & & 539482 \\
\hline 2001/2002 & & 6290 & 7100 & 19 April & 225 & 14 May & 646832 \\
\hline 2002/2003 & & 6290 & 7164 & $13 \mathrm{Feb}$. & & & 385538 \\
\hline $2003 / 2004$ & & 6290 & 7100 & 19 April & 75 & 14 May & 619766 \\
\hline 2004/2005 & & 6290 & 7115 & 7 April & 198 & $29 \mathrm{Jan}$ & 560561 \\
\hline $2005 / 2006$ & & 6290 & 8662 & 14 April & 270 & $23 \mathrm{Apr}$ & 841827 \\
\hline 2006 & 947603 & & & & & & \\
\hline NPV & & & & & & & 3809870 \\
\hline Annuity & & & & & & & 493396 \\
\hline
\end{tabular}

Ewes present at start of lambing ${ }^{2}$ Average sale date

Table 5 Summary of farm system and financial analysis with Base legume on LMUs 1 \& 4 and Low legume on LMUs 2 \& 3.

\begin{tabular}{|c|c|c|c|c|c|c|c|}
\hline & \multirow[t]{2}{*}{ Stock Value (\$) } & \multirow[t]{2}{*}{ Ewes' ${ }^{1}$} & \multicolumn{2}{|c|}{ Lambs Sold } & \multicolumn{2}{|c|}{ Cattle Sold } & \multirow[t]{2}{*}{ EBITDA (\$) } \\
\hline & & & Head & Date $^{2}$ & Head & Date $^{2}$ & \\
\hline 1996 & -846909 & & & & & & \\
\hline 1996/1997 & & 4697 & 5310 & 7 April & 30 & $29 \mathrm{Jan}$. & 355595 \\
\hline 1997/1998 & & 4697 & 5282 & 16 May & & & 492997 \\
\hline 1998/1999 & & 4697 & 5301 & 20 April & & & 439453 \\
\hline 1999/2000 & & 4697 & 5305 & 14 April & & & 429366 \\
\hline 2000/2001 & & 4697 & 5305 & 15 April & & & 385648 \\
\hline 2001/2002 & & 4697 & 5289 & 6 May & 130 & 15 May & 498306 \\
\hline 2002/2003 & & 4697 & 5350 & 12 Feb. & & & 263829 \\
\hline 2003/2004 & & 4697 & 5282 & 16 May & & & 493723 \\
\hline 2004/2005 & & 4697 & 5306 & 16 April & 98 & 26 Jan. & 417182 \\
\hline 2005/2006 & & 4697 & 6466 & 16 April & 181 & 4 June & 629769 \\
\hline 2006 & 707521 & & & & & & \\
\hline NPV & & & & & & & 2957350 \\
\hline Annuity & & & & & & & 382990 \\
\hline
\end{tabular}

${ }^{1}$ Ewes present at start of lambing ${ }^{2}$ Average sale date

To estimate the value of additional legume to the investment, based on a $5 \% /$ year discount rate. farm system it was necessary to account for the different capital investments and liquidation at the end of the planning horizon and the variable annual EBITDAs. Comparing NPVs for the options modelled provides this. The increase in NPV/ha from increasing legume from Base to High (\$1251) is slightly more than would be achieved in moving from Low to Base $(\$ 1161)$. This can be interpreted as spending $\$ 1161$ to move legume proportion from Low to Base would be a break-even

Comparison of different proportions of legume across individual LMU

The legume proportion was altered in each group of LMUs to provide the farm system details to enable comparisons between levels of legumes. The farm systems summaries (Tables 5, 6 and 7) for the remaining 3 combinations identified in Table 1 (Base-Low,

Table 6 Summary of farm system and financial analysis with High legume on LMUs 1 \& 4 and Low legume on LMUs 2 \& 3.

\begin{tabular}{|c|c|c|c|c|c|c|c|}
\hline \multirow[t]{2}{*}{ 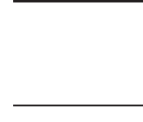 } & \multirow{2}{*}{ Stock Value (\$) } & \multirow[t]{2}{*}{ Ewes $^{1}$} & \multicolumn{2}{|c|}{ Lambs Sold } & \multicolumn{2}{|c|}{ Cattle Sold } & \multirow[t]{2}{*}{ EBITDA (\$) } \\
\hline & & & Head & Date $^{2}$ & Head & Date $^{2}$ & \\
\hline 1996 & -948392 & & & & & & \\
\hline 1996/1997 & & 4897 & 5443 & 11 April & 106 & 29 Jan. & 365679 \\
\hline 1997/1998 & & 5259 & 5920 & 10 May & 41 & 20 March & 556558 \\
\hline 1998/1999 & & 5259 & 5936 & 20 April & & & 509663 \\
\hline 1999/2000 & & 5259 & 5945 & 09 April & & & 491635 \\
\hline 2000/2001 & & 5259 & 5941 & 14 April & & & 452300 \\
\hline 2001/2002 & & 5642 & 6451 & 02 May & 77 & 04 June & 560159 \\
\hline 2002/2003 & & 5259 & 5990 & 13 Feb. & & & 321728 \\
\hline 2003/2004 & & 5259 & 5922 & 07 May & 37 & 04 June & 542206 \\
\hline 2004/2005 & & 5259 & 5944 & 14 April & 158 & 29 Jan. & 470177 \\
\hline 2005/2006 & & 5259 & 7244 & 13 April & 226 & 04 June & 715248 \\
\hline 2006 & 792302 & & & & & & \\
\hline NPV & & & & & & & 3346030 \\
\hline Annuity & & & & & & & 433326 \\
\hline
\end{tabular}

${ }^{1}$ Ewes present at start of lambing ${ }^{2}$ Average sale date

Table 7 Summary of farm system and financial analysis with High legume on LMUs 1 \& 4 and Base legume on LMUs 2 \& 3.

\begin{tabular}{|c|c|c|c|c|c|c|c|}
\hline \multirow[t]{2}{*}{ 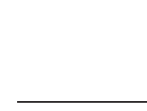 } & \multirow[t]{2}{*}{ Stock Value (\$) } & \multirow[t]{2}{*}{ Ewes $^{1}$} & \multicolumn{2}{|c|}{ Lambs Sold } & \multicolumn{2}{|c|}{ Cattle Sold } & \multirow[t]{2}{*}{ EBITDA (\$ } \\
\hline & & & Head & Date $^{2}$ & Head & Date $^{2}$ & \\
\hline 1996 & -1048090 & & & & & & \\
\hline 1996/1997 & & 5023 & 5484 & 7 April & 187 & $25 \mathrm{Feb}$. & 348575 \\
\hline 1997/1998 & & 5812 & 6549 & 3 May & 42 & 12 Feb. & 599446 \\
\hline 1998/1999 & & 5812 & 6565 & 15 April & & & 561815 \\
\hline 1999/2000 & & 5812 & 6574 & 5 April & & & 545965 \\
\hline $2000 / 2001$ & & 5812 & 6570 & 9 April & & & 496979 \\
\hline 2001/2002 & & 6059 & 6896 & 24 April & 148 & 4 June & 610481 \\
\hline 2002/2003 & & 5812 & 6619 & 14 Feb. & & & 357074 \\
\hline $2003 / 2004$ & & 5812 & 6556 & 25 April & 57 & 4 June & 581880 \\
\hline 2004/2005 & & 5812 & 6571 & 10 April & 177 & 29 Jan. & 527297 \\
\hline 2005/2006 & & 5812 & 8004 & 14 April & 244 & 12 May & 785810 \\
\hline 2006 & 875590 & & & & & & \\
\hline NPV & & & & & & & 3614490 \\
\hline Annuity & & & & & & & 468093 \\
\hline
\end{tabular}




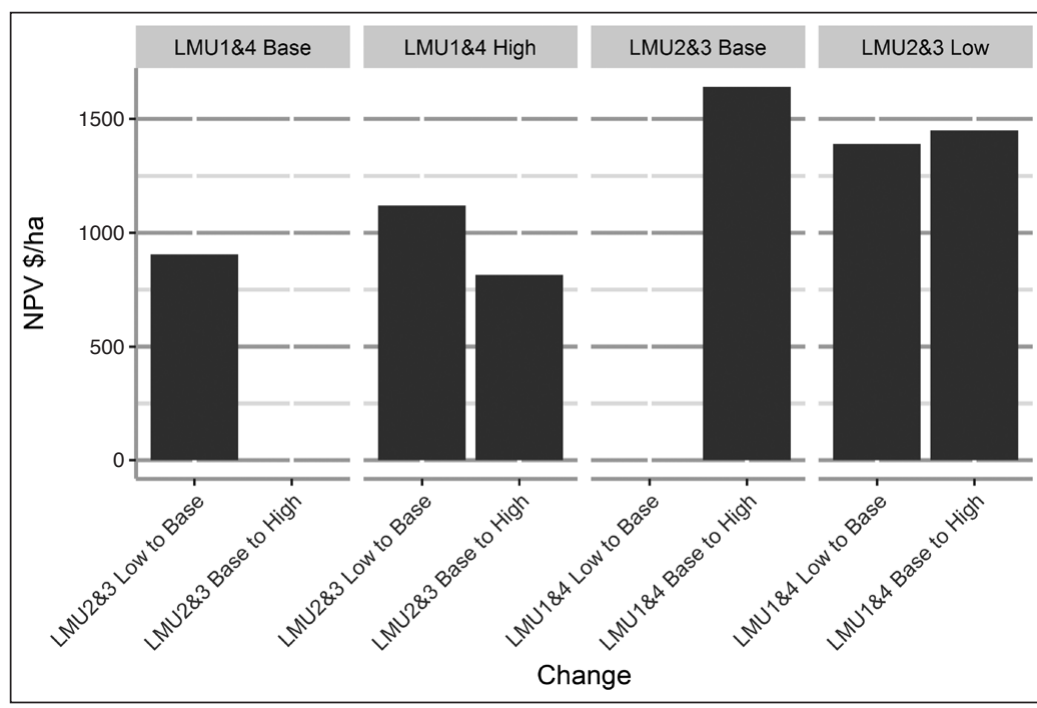

Figure 1 Change in NPV ( $\$ / h a)$ due to changes in legume proportion on different areas of the farm (LMU1 \& 4 total 268 ha and 1 \& 3 total 240 ha).

the previous 3 combinations (Low, Base and High), namely different levels of investment (and liquidation) in capital livestock, cattle being purchased to finish in some years, and lamb sales dates and EBITDA varying across years in all systems. Also, no replacement ewe lambs were retained in the final $(2005 / 2006)$ year, rather they were sold prime

The value of altering the legume proportion of the pasture on different LMUs was estimated by comparing the NPV's of the options modelled (Figure 1). The blank options in Figure 1 were not evaluated as that would have resulted in the lower producing LMU $(2 \& 3)$ having a greater legume proportion than the higher producing LMUs ( 3 \& 4), which would be unlikely due to the physical characteristics of the LMUs (slope, aspect, etc.). In all cases increasing the legume proportion led to higher NPV. The increase in NPV/ ha was always greater when the legume proportion was increased on the higher performing LMUs ( $1 \& 4)$ than lower performing areas of the farm. This would be expected as they have greater pasture production. The greatest contribution to increasing legume proportion in the lower producing LMUs (2 \& 3) came from increasing legume proportion from Low to Base when the legume proportion in the good LMUs were at High level. Wheres in the beter LMUs (1 returns came from incesing legus High with Base legume proportion in the poorer LMUs. This indicates that the responses were not linear.

\section{Discussion}

There is clearly a value to the farm of increasing legume proportion in the sward (Lambert et al. 1986; Fraser \&
Rowarth 1996; Chapman \& Caradus 1997), allowing for the change in capital invested in livestock. This has been also shown by Khaembah et al. (2012) in modelling a pasturebased Waikato dairy farm, although cow numbers aere held constant and the were held cow the analysis modelled the farm as three independent years. This analysis identifies that between $\$ 800$ and $\$ 1600 /$ ha is returned from increased levels of legumes, depending upon the current level of legume and the pasture prodution of the pasture production of the blocks. Note that the cost of capital stock has been included in the analysis. However, the question that needs to be answered is how much can be spent on the capital investment to make a worthwhile return, allowing for such factors as establishment risk, market risk, owners risk profile and the businesses current financial position.

The analysis undertaken provides an estimate, from a strategic perspective, of the maximum that could be spent to be economically profitable. This would give direction to those wanting to invest in extra pasture legume as well as researchers looking at new ways to introduce and manage extra legumes. This approach could also be used in legume breeding programmes to estimate the economic weights used in a selection index for pastoral grazing farm systems.

Extension of this analysis to other locations or mix proporions of different lane farm will define the value of additional leguke up arm will define the value of additional legume.

There are a number of shortfalls in the analysis, that whilst they may change the absolute values would be unlikely to change the result. In estimating the grass growth in the Low level of legumes it was assumed that there would not be change in grass species from that present in the Base. It is more likely that lower fertility grase we change in the shape of the pasture growth curve. This is likely to mean that the farm systems involving Low legume proportion have EBITDA's and NPV's that are overestimated. Therefore, the size of the difference may be larger than indicated in Figure 1.

It has also been assumed that the extra growth from having High legume will be sustained over time. It is likely that the extra legume would result in fluctuations of pasture growth between periods. The extra nitrogen fixed would result in increased competition for the legume and hence increase grass production followed by the opposite as legume regains a foothold. The other assumption made with the High legume option is that the increased pasture growth rates are actually achievable with the climate, altitude, aspect, slope and soil type that exists on the LMU.

The options modelled will be overestimates of what may happen in reality. The model has perfect and complete information about the whole planning horizon. A farm manager only has information available up to the day a decision is being made. However, the differences among the options should be comparable on a relative basis and be sufficient to inform better decision making.

\section{Conclusion}

As expected increasing the amount of legume in the pasture and therefore in the diet of farm animals leads to both a change in the farm system and a change in farm profitability. The change in capital stock numbers in the farm system, necessitated that an investment analysis be undertaken. This identified that the Whanganui hill country case-study farm could benefit between $\$ 800$ and $\$ 1600 /$ ha from additional legumes, depending upon the areas of the farm that were identified for improvement. This does not include the cost of increasing the legume content. The areas with the greatest potential return were those in the areas of the farm that had the greatest pasture production. Furthermore, the benefit varied with the base level of legume in the pasture.

\section{ACKNOWLEDGEMENTS}

Dougal and Di McIntosh for allowing us to use their farm for this case study. The P21 consortio (Beef + Lamb New Zealand, MBIE, DairyNZ, AgRent for fi AgResearch) for funding. Gerald Cosgrove, Andrew Wall and the two anonymous referees that added to the clarity of the manuscript.

\section{REFERENCES}

Ball, R.; Brougham, R.W.; Brock, J.L.; Crush, J.R.; Hoglund, J.H.; Carran, R.A. 1979. Nitrogen fixation in pasture. 1. Introduction and general methods. New Zealand Journal of Experimental Agriculture 7: $1-5$.

Chapman, D.F.; Caradus, J.R. 1997. Effects of improved, adapted white clover (Trifolium repens L.) germplasm on the productive properties of a hill pasture. New Zealand Journal of Agricultural Research 40: 207-221.

Fraser, T.J.; Rowarth, J.S. 1996. Legumes, herbs or grass for lamb performance? Proceedings of the New Zealand Grassland Association 58: 49-52.

Freer, M.; Moore, A.D.; Donnelly, J.J. 2012. The GRAZPLAN animal biology model for sheep and cattle and the GrazFeed decision tool. CSIRO Plant Industry Technical Paper Dec 2012.

Gray, M.H.; Korte, C.J.; Christieson, W.M. 1987. Seasonal distribution of pasture production in New Zealand XX. Waerengaokuri (Gisborne). New Zealand Zeurnal of Experimental Agriculture 15:397 Z

Holmes, C.W.; Brookes, I.M.; Garrick, D.J. MacKenzie, D.D.S.; Parkinson, T.J.; Wilson, G.E 2002. Milk Production from pasture: principles and practices. Massey University, Palmerston North, New Zealand. 602 pp.

Khaembah, E.N.; Gregorini, P.; Beukes, P.; Cosgrove, G.P. 2012. Modelling the effect of increasing dietary proportion of white clover on cow milk production priton of white clover on cow milk production dairy farm. Proceedings of the 5th Australasian Dairy Science Symposium: 146-149.

Lambert, M.G.; Clark, D.A.; Grant, D.A.; Costall, D.A 1986. Influence of fertiliser and grazing managemen on North Island moist hill country 2. Pasture botanica composition. New Zealand Journal of Agricultural Research 29: 1-10.

Lambert, M.G.; Mackay, A.D.; Devantier, B.P.; McDougall, D.B.; Barker, D.J - Park-Ng, Z.A. 2003. Redefining the production potential of hill pastures using fertiliser nitrogen. Proceedings of the New Zealand Grassland Association. 65: 35-40.

Ledgard, S.F.; Sprosen, M.S.; Penno, J.W.; Rajendram, G.S. 2001. Nitrogen fixation by white clover in pastures grazed by dairy cows: Temporal variation and effects of nitrogen fertilization. Plant and Soil 229: 177-187.

Nelson, T.A.; Zydenbos, S.M.; Stevens, D.R. 2017. Information required from research programmes when introducing legume forage systems into challenging environments. Journal of New Zealand Grasslands 79: 135-138.

Rendel, J.M.; Mackay, A.D.; Manderson, A.; O'Neill, K. 2013. Optimising farm resource allocation to maximise profit using a new generation integrated whole farm planning model. Proceedings of the New Zealand Grassland Association 75: 85-90.

Rendel, J.M.; Mackay, A.D.; Smale, P.N. 2015. Valuing on-farm investments. Journal of New Zealand Grasslands 77: 83-88

Rendel, J.M.; Mackay, A.D.; Smale, P.N.; Vogeler, I. 2016. Moving from exploring on-farm opportunities with a single to a multi-year focus: Implications for decision making. Journal of New Zealand Grasslands 78. 57-66. 